\title{
HOW BIASED IS THE BEHAVIOR OF THE INDIVIDUAL INVESTOR IN WARRANTS?
}

Margarida Abreu

\section{REM Working Paper 007-2017 \\ October 2017}

\section{REM - Research in Economics and Mathematics \\ Rua Miguel Lúpi 20, \\ 1249-078 Lisboa, \\ Portugal}

ISSN 2184-108X

Any opinions expressed are those of the authors and not those of REM. Short, up to two paragraphs can be cited provided that full credit is given to the authors.

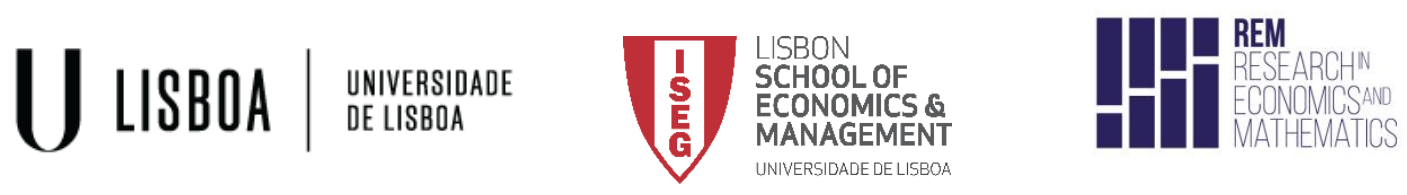


ISEG (Lisbon School of Economics \& Management) - Universidade de Lisboa Rua do Quelhas, 6, 1200-781 Lisboa, Portugal

Tel.: +351-213925800

E-mail: mabreu@iseg.ulisboa.pt

http://www.iseg.utl.pt/

UECE (Research Unit on Complexity and Economics) -REM

Rua Miguel Lupi, 20, 1249-078 Lisboa, Portugal

Tel.: +351 - 213925912

\section{SUMMARY}

Based on the actual trading behavior of individual investors in the Portuguese financial market during almost ten years this paper examines the socio-demographic characteristics of retail investors in warrants, and discusses the hypothesis that some behavioral biases do have an impact on the investors' predisposition to invest and trade in warrants, a complex financial instrument. One finds that there is a profile of investors in warrants: younger and less educated men are more likely to invest in warrants and that overconfident, disposition-prone and investors exhibiting a gambling attitude are more likely to invest and trade in warrants. Secondly, the gambling motive seems to be a distinguishing characteristic of investors in warrants. In other words, when investors are driven to trade in financial markets for pleasure/fun they tend to trade complex products more and to trade simple and easier to understand financial instruments less. Finally, the higher the intensity of trading the more relevant are the disposition and the gambler's biases.

\section{KEYWORDS}

Warrants, overconfidence, disposition effect, gambling effect, individual investor behavior

\section{JEL CODES}

G41, G11, G12

\footnotetext{
${ }^{1}$ ISEG - Universidade de Lisboa, Department of Economics; UECE - Research Unit on Complexity and Economics, R. Miguel Lupi 20, 1249-078 Lisbon, Portugal, email: mabreu@iseg.ulisboa.pt. UECE is supported by the Fundacão para a Ciência e a Tecnologia (Portuguese Foundation for Science and Technology). This article is part of the Strategic Project (UID/ECO/00436/2013).
} 


\section{HOW BIASED IS THE BEHAVIOR OF THE INDIVIDUAL INVESTOR IN WARRANTS?}

\section{Introduction}

In spite of the success that warrants have had in some financial markets, little is known regarding the profile of those most likely to invest in this complex financial instrument. This paper looks to define the profile of the investor in warrants and searches for non-rational motives that may explain the success of the market for warrants among individual investors. Based on the actual trading behavior of individual investors in the Portuguese financial market during almost ten years, I examine the socio-demographic characteristics of the investors in warrants and discuss the hypothesis that some behavioral biases influence the individual investors' predisposition to invest and trade in warrants. More precisely, I empirically examine the hypotheses that overconfidence, the disposition effect and the pleasure of gambling have an impact on the participation and trading in warrants, controlling for investors' socio-demographic characteristics. Moreover, I search for profile and behavioral biases differences between investors that trade intensely in warrants and investors that only trade less frequently.

Overconfidence is probably the most widely studied and well-established behavioral bias. Generally defined as people's tendency to overestimate their knowledge, abilities and the precision of their information, as well as their capacity to estimate and control future events, overconfidence has been defined in different dimensions: miscalibration (cf. Lichtenstein et al. 1982, Fischhoff et al. 1977 or Daniel et al. 1998), better-than-average effect or illusion of control (Thompson, 1999). 
Those different dimensions of overconfidence are interconnected. For example, people who are overconfident about their abilities tend to overestimate their influence over outcomes. For that reason, one could argue that overconfidence is best apprehended by its consequences. The most widely recognized consequence of overconfidence is that it induces higher trading volume. Overconfident investors, either because they overestimate the precision of the information they have, or because they think they have above average investment skills, trade more than rational investors. For De Bondt and Thaler (1995) overconfidence is the key behavioral factor needed to understand the overtrading puzzle. Odean (1998b) argues that the high level of trading volume is the most important effect of overconfidence. Statman et al. (2006) presents empirical evidence for the US market and argues that trading volume is particularly higher after high returns, as investment success increases the degree of overconfidence.

However, the different dimensions of overconfidence do not measure the same thing and research shows that they do not induce the same errors in the financial behavior of individual investors. Investor's unrealistic tendency to believe that their abilities, knowledge and overall capacity to analyze available information are better than average may have a particular impact on trading behavior, particularly for investors with high past performance.

The intuition behind this argument is that the accumulation of successful market investments makes investors increasingly overconfident and consequently makes them trade more. Due to a self-attribution bias, investors think they are above average regarding their investment skills. This better than average effect has been documented empirically by Glaser and Weber (2007) who provide evidence of a higher trading propensity by overconfident investors when they identify overconfident 
investors as those who think they are better than average in terms of investment skills or past performance. This finding is also consistent with other studies (see Deaves et al. 2009, Graham et al. 2009).

The disposition effect is another important bias in finance, because it is costly. In fact, investors who show this bias usually hold poorly diversified portfolios and end up making bad financial decisions that are contrary to rational models of investment. Labeled by Shefrin and Statman (1984), the disposition effect describes the tendency that investors have to sell securities whose price is rising, the so-called winners, while keeping in portfolio securities whose price is declining, the losers.

Three rational motives may justify the disposition effect: portfolio rebalancing, trading costs, and tax-related motives for selling stocks at a loss. However, Odean (1998a) finds disposition effect even after controlling for portfolio rebalancing and trading costs, and Lakonishok and Smidt (1986) considers that the disposition effect dominates tax-related motives for selling stocks at a loss. Several other empirical papers have also documented the existence of disposition effect (Grinblatt and Keloharju 2001, Shapira and Venezia 2001, Dhar and Zhu 2002).

Much of the behavioral finance literature relates the disposition effect to loss aversion. Investors value a title gain or loss relatively to a reference point, usually the purchase price of the asset. When transactions are carried in the financial market, agents will evaluate their portfolio and whether the assets have appreciated or depreciated vis-a-vis the purchase price. Combining the analysis of the reference point with the fact that investors are risk averse in the domain of gains and risk seekers in the domain of losses, it is easy to understand that if the asset price falls and remains below the reference point, investors, who value losses more than gains, will be averse to sell that asset for a loss, causing a reduction in the supply of potential sellers. A 
losing stock would be considered a loss and being risk-seeker in this domain would cause the investor to hold the stock. However, other behavioral finance justifications have been added to explain the disposition effect. Barberis and Xiong (2009) concludes that the investors' tendency for selling winning stocks too early and holding losing stocks too long depends on the success of past investments. If past investments where set at a gain, the agents will be progressively less risk averse and will show more disposition effect. Muermann and Volkman (2006) focuses on how anticipating regret and pride in a dynamic setting may cause investors to optimally follow a strategy in which they sell winning stocks and hold losing stocks; that is, on how anticipating regret and pride contribute to explain the disposition effect. Summers and Duxbury (2012) favors emotion over prospect theory to explain the disposition effect.

The pleasure of gambling is also important to understand individual investors' behavior. It refers to the classical hedonic motivational principle that people approach pleasure and avoid pain. This pleasure-seeking motivation should be considered in a wide context, associated with other types of positive emotions (Proyer 2017 mentions interest or contentment). Some people trade in financial markets only because trading brings the joy of gambling. Dorn and Sengmueller (2009) examines the hypothesis that entertainment motives drive trading by combining survey responses and transaction records for a sample of more than 1,000 clients at one discount broker in Germany. The authors conclude that although investors do not only trade for entertainment purposes, clients classified as potentially entertainment-driven trade more than their peers. In addition, entertainment-driven investors turn over their portfolio of stocks, bonds, funds and options at roughly twice the rate of their peers. In the same line of reasoning some authors argue that investors who are more prone to sensation seeking trade more frequently. According to Zuckerman (1994), "sensation 
seeking is a trait defined by the seeking of varied, novel, complex, and intense sensations and experiences, and the willingness to take financial risks for the sake of such experience."2 As Grinblatt and Keloharju (2009) puts it, for investors prone to sensation seeking "the mere act of trading and the monitoring of a constant flow of 'fresh stocks' in one's portfolio may create a more varied and novel experience than a buy and hold strategy". ${ }^{3}$

This study adds to the existing literature on derivative products in some important aspects. Firstly, I analyze the relative importance of overconfidence, disposition and gambling as drivers for the individual investment and trading in warrants (a complex financial product), comparing to the investment and trading in stocks. Secondly, as far as I know this is the first study that analyzes whether investors who invest and trade more frequently have a different profile than other investors who trade less frequently. Lastly, unlike most empirical studies the design of this research combines actual trading behavior of retail investors with a survey of these investors conducted by a securities regulator (the Portuguese securities commission).

I start out documenting that investors in warrants are indeed different, not only because they have specific socio-demographic characteristics but they also reveal specific behavioral biases. Overconfident investors and investors who exhibit a disposition or a gambling attitude are more likely to invest in warrants. Next, investor's trading activity is studied and the hypothesis that investors in warrants trade differently than investors in stocks is tested. Results show that warrants trading activity increases with overconfidence, disposition and gambling. The warrants' market differs from de

\footnotetext{
${ }^{2}$ Cf. Zuckerman (1994), p.27.

${ }^{3}$ Cf. Grinblatt and Keloharju (2009), p.556.
} 
stock market in the sense that the search for pleasure seems to increase warrants transactions but decreases stock trading activity. In other words, when investors are driven to trade in financial markets for pleasure they tend to trade complex products more and to trade simple and easier to understand financial instruments less. Finally, I control for the time span in which the investor is active in the market, splitting investors according to their intensity of trading. I find that disposition and gambler's effects are more relevant to explain the frequency of trading the higher the intensity, but they are of no help to understand the top quantile traders. High trading frequency investors seem to be more heterogeneous and without a clear-cut socio-demographic and behavioral profile. The remainder of this paper is organized as follows. The next section describes the databases used and the construction of the behavioral variables used in the paper. The third section traces the socio-demographic profile of investors in warrants and studies the importance of overconfidence, disposition and gambling as determinants of the decision to participate in the market for warrants. In section 4 the trading activity in stocks and warrants is studied. Section 5 analyses the trading frequency and investors are split according to their intensity of trading in warrants. In the last section I draw some final conclusions.

\section{Data and variable construction}

\subsection{Data}

The main database used in this study (the trading database) contains information from one of the top three Portuguese banks, with a market share of $15 \%$ to $20 \%$. The information relates to all the existing accounts of individual (ie, retail) investors and includes the demographic data (marital status, birth date, gender, education, 
occupation and residence) of the first account holder. In addition, it includes information on all transactions in financial instruments linked to these accounts for the period $02 / 01 / 1997$ to $16 / 09 / 2006$. This information includes the date of the transaction, the transaction type (purchase or sale), the ISIN code of the financial instrument, the quantity traded and at what price.

In the period of almost ten years covered by this database, 3,620 investors traded warrants and 491,540 traded stocks. This means that for every 136 equity investors only one traded warrants, which is to say that the market of this derivative instrument is composed of a small percentage of the Portuguese population. It is difficult to establish a comparison with other countries and jurisdictions, because this kind of information is not easily available. Nevertheless, it is possible to compare this percentage with the one in Hong-Kong: according to SFC (2006), 12.6\% of individual investors in Hong-Kong had made transactions in warrants, which is a percentage far higher than the Portuguese one. This may reflect the programs of privatization carried out by successive governments that led many Portuguese families to invest in the stock of firms being privatized during this period, as well as the greater complexity of warrants (in comparison with stocks) that discourages the investment in this financial instrument. It is also the result of the late introduction of this derivative instrument in Portugal. In fact, detachable warrants came into Portuguese legislation in 1988 (Decree-Law No. 229-B/88 of July 4): bonds may have detachable warrants, and the bondholder has a warrant that confers on him the right to acquire shares at a price under predetermined conditions. This warrant is detached from the bond and can be freely traded on the stock market regardless of the bond it was detached from. Subsequently, Decree-Law No. $172 / 99$ of May 20 was approved, which was followed 
by Regulation No. 19/99 of the CMVM (the Portuguese Securities Supervisor), dated November 10th, both of which established the legal framework of covered warrants. The first issue of detachable warrants in Portugal was led by the Banco Comercial de Macau, in 1990, and the first issue of covered warrants was led by Banco Santander in September 2000 (Mendes 2012).

Thus, it is not surprising that in the period covered by the database the total number of trades in stocks (more than 3.8 million) is much greater than the total number of trades in warrants (slightly above 0.2 million), or that the average number of trades in warrants (stocks) per investor is $58.3(7.8) .{ }^{4}$ Indeed, many investors had their first contact with the stock market following the privatization of state-owned firms, but acquired the shares in a purely buy-and-hold strategy or sold them later without having invested in new stocks. On the contrary, the greater complexity of warrants may have led some investors to specialize in this derivative instrument and, consequently, to be much more active, buying and selling on market expectations that they have regarding the future prices of the underlying assets.

However, the sample used in the following sections is restricted to less investors. Firstly, only investors who trade in stocks are selected from the database, and I exclude investors living abroad. I also exclude what I name 'curious investors', that is, investors who have only traded once in either stocks or warrants. Some of these investors in stocks also invest and trade in warrants, and after the exclusion of some observations for which there is not sufficient information, I end up with a sample of 52,768 investors in stocks, off which 1,705 also trade warrants during the period

\footnotetext{
${ }^{4}$ In the database used by Schmitz et al. (2007) the average investor made 55 transactions in warrants. However, the time period covered is only 51 months, shorter than the one used here.
} 
covered by the dataset. The activity of investors in warrants is illustrated in this smaller sample by the total number of trades in stocks $(743,340)$ which is more than 7 times higher than the total number of trades in warrants $(102,314)$; the average number of trades per investor is 79.0 trades in warrants and only 13.6 trades in stocks (the maximum is 3,374 and 2,232 trades in warrants and stocks, respectively).

A different database is also used. It comes from a survey conducted by CMVM to identify the characteristics of Portuguese individual investors. ${ }^{5}$ The most recent one was conducted in 2000, and was publicly released in May 2005 on the CMVM website. More than fifteen thousand individuals were contacted between 2 October and 22 December 2000 using the direct interview technique. These individuals were responsible or co-responsible for the investment decisions within the family. All the identified investors in securities $(1,559)$ were interviewed using a structured questionnaire. Each questionnaire included socio-demographic questions, questions related to the nature and type of the assets held and investor experience, but there are no questions related to the size of the portfolio, nor the amounts invested in each type of asset. There are also questions related to investor's trading behavior (frequency of transactions, sources of information used, etc.) and to investor's knowledge about markets and market players. This database is used to compute proxies for the better than average and the gambling attitude towards the investment in derivatives variables.

\footnotetext{
${ }^{5}$ The survey identifies an investor in securities as one holding one or more of the following assets: stocks, bonds, mutual funds, participation certificates and derivatives.
} 


\subsection{Behavioral variables}

Two approaches are used to deal with the overconfidence issue. Firstly, the approach of Goetzmann and Kumar (2008) and Bailey et al. (2008) is followed, and an investor is considered overconfident if his trading activity is in the top quartile of the distribution on investors' trading activity (i.e., are in the upper quartile of the number of trades in stocks) and his performance is in the bottom quartile of the distribution of investors' stock returns. This definition is based on the idea that overconfident investors trade too much and consequently get lower returns for their investments (Odean 1999, Barber and Odean 2000). The variable so defined is labeled OVERCONFIDENCE.

Alternatively, I also use the better than average concept. Overconfident investors are defined as those who believe that they know more than they actually do, this being measured by the difference, if positive, between self-reported financial knowledge and actual financial knowledge. The self-reported financial knowledge variable is based on the survey question: "How do you rate, on a 1 (very low) to 7 (very high) scale, your own knowledge of financial assets and markets?". Investors' answers to this question are compared with an actual knowledge variable measured in the 1 to 7 scale, which comes out of the survey as well.

Three of the survey questions (questions 7,11 combined with $11 \mathrm{~A}$, and 13) are used to compute investors' actual knowledge. In the survey, investors are asked to name companies with shares or bonds listed, up to a maximum number of 5 (question 7). Responses to this answer are marked from 0 to 5, 0 meaning that investor fails to mention the name of any company, and 5 that he correctly named 5 companies with shares or bonds listed. In question 11A (and in question 11) investors are asked 
whether they know any of the following entities: BVLP, Interbolsa, CMVM, Credit Institutions, Dealers. Again, answers are marked from 0 to 5 , with 0 meaning that investors are unaware of these entities and 5 that they know them all. Finally, question 13 is the following: "If you wish to file a complaint about a financial intermediary, an issuer or any other entity related with the securities markets, to whom would you address it?" Answers are marked with 5 if CMVM is mentioned and with 0 if no entity (or a wrong one) is identified. The unweighted average of the answers obtained to these three questions, converted to the 1 to 7 scale, is used as a proxy for the actual knowledge of individual investors, higher values meaning that investors have a better understanding of financial markets.

If the difference between the self-reported and the actual knowledge is positive and greater than 0.9 then BETTER THAN AVERAGE $=1 .{ }^{6} \mathrm{I}$ then regress this better than average variable on a set of socio-demographic investor characteristics, using the investors' characteristics from the CMVM survey. In a second step, the estimated coefficients of this linear probability model (LPM) are used to predict whether investors in the trading database are (are not) better than average. I now use the sociodemographic investor characteristics from the trading database and the estimated LPM coefficients to estimate whether investors are better than average, again using an LPM model. Assuming that the percentage of investors with this bias in the trading database is equal to the percentage of better than average investors in the survey, BETTER THAN AVERAGE $=1$ for the investors with the higher score in the model estimated in the second step of the procedure.

\footnotetext{
${ }^{6}$ Different limits were used and the results are robust.
} 
To access the hedonic motive for investment I construct the GAMBLING variable, with a procedure similar to that of the better than average variable. Investors are considered to have a gambling attitude towards the investment in financial markets when they do not get any information regarding financial markets and products and yet they trade financial instruments, whichever they are. From the CMVM's survey the socio-demographic characteristics of the investors who do not use any source of information to get informed on financial markets and products are analyzed, and I assume that these investors do have a gambling attitude because they invest and trade in financial instruments without getting any information on financial markets and products. Firstly, this gambling variable is regressed on a set of socio-demographic characteristics of investors, using the investor's characteristics from the survey. In a second step, the estimated coefficients of this model are used to predict which investors in the transactions database have a gambling attitude. Assuming that the percentages of investors with a gambling attitude are similar in the survey and in the main trading database, GAMBLING = 1 for the investors with the higher scores in the estimated gambling LPM model from the second step.

As regards the DISPOSITION proxy, I follow the Goetzmann and Massa (2003) methodology. Firstly, each transaction in stocks is classified as "trade at loss" or "trade at gain". ${ }^{7}$ Then, for each stock in the portfolio, a time series of the trades (sales and buys) at loss and trades at gain is constructed. For example, when a sale happens, I compute the difference between the sell price and the price at which the previous purchase of that stock occurred. Negative differences (sale price lower than the buy price) are recorded as sale at loss, and positive differences as sale at gain. Buys are

\footnotetext{
${ }^{7}$ I assume a LIFO criterion (the last shares bought are the first ones to be sold) to identify sales at loss.
} 
treated in a similar fashion; in these cases the price that occurred in the previous trade of the same stock (regardless of it being a sale or a purchase) is used as the reference price. Given that disposition investors tend to sell winning stocks (that is, sell at gain) and buy losing stocks (that is, buy at loss), for each stock I compute the ratio between buys at loss plus sells at gain minus sells at loss minus buys at gain, standardized by the sum of buy at loss, buy at gain, sell at loss and sell at gain. Adding up for all stocks in the portfolio, if this ratio is positive, then the investor exhibits disposition effect, and if not positive the investor dos not exhibit disposition effect. Thus, DISPOSITION = 1 if that ratio is positive, and zero otherwise.

\section{The participation decision}

I use a probit model to distinguish the characteristics of investors who traded in both warrants and stocks from those who only traded stocks (that is, the decision to participate in the market for warrants). The base probit model is the following:

Warrant $=f($ Male, Age, Married, Education, Job, Place of Residence $)$

where ${ }^{8}$ :

- Warrant is a binary variable, equal to 1 if the investor trades in warrants during the period, and zero otherwise (that is, the investor trades in stocks but not in warrants);

\footnotetext{
${ }^{8}$ I do not include wealth or income variables because the database does not have any information directly linked to these variables, thus preventing the inclusion of these aspects in the model.
} 
- Male is a gender variable, equal to 1 if the investor is male;

- Age is the age of the investor in years, defined as (2006 minus the year of birth of the account holder);

- Married is the marital status of the investor, and is equal to 1 if he/she is married;

- Education is the level of education. Three categories are considered: Low $=1$, if the investor has 4 or less years of education; Average $=1$, if the investor has more than 4 but 12 or less years of education; High $=1$, if a technical or higher course was completed by the investor;

- Job represents the occupation of the investor. Five categories are considered: Highly skilled $=1$, if the investor is a business manager, director or is in the upper levels of public administration; Skilled $=1$, if the investor is an office work or similar; Low skill $=1$, if farmer, industrial worker, mechanic or non-qualified worker; Independent workers $=1$, if the investor is a liberal professional (that is, works but does not have a tenured position in a company); and Inactive $=1$, if the investor is retired, unemployed or student;

- Place of Residence represents the region of residence of the investor. Three categories are considered: Lisbon $=1$ if the investor lives in Lisbon; Porto $=1$ if living in Porto; Other $=1$ if the investor does not live in Lisbon or in Porto. ${ }^{9}$

The literature considers that more risk-tolerant behavior is associated with younger investors who do not have family responsibilities within marriage, and that more qualified professions are generally associated with a higher income level and

\footnotetext{
${ }^{9}$ Four or less years of education, inactive workers (mostly retired), and residence outside Lisbon and Porto are the omitted categories in all the regressions.
} 
thus permit taking higher risks. In fact, it has been shown that investors' behavior depends on socio-demographic characteristics: age (DaSilva and Giannikos 2006), occupation (Christiansen et al. 2008) or the environment in which they live (Goetzmann and Kumar 2008). Barber and Odean (2001) and Goetzmann and Kumar (2008), for example, report evidence that married investors, women and older investors have less appetite for risk. On the other hand, higher levels of education have been positively associated with greater sophistication. Related to this literature, recent works on financial literacy show that the higher the individual knowledge, the more efficient and rational will be her/his financial behavior, such as planning and saving for retirement (Lusardi and Mitchell 2009), investing in the stock market (Christelis et al. 2010) or diversifying portfolio (Abreu and Mendes 2010).

Calvet et al. (2009) concludes that seemingly irrational behavior diminishes substantially with investor wealth. I attempt to control for investors' wealth by controlling for their job (the closest proxy for wealth insofar as neither the survey nor the trading database have an income or wealth variable). To that end, dummy variables are used to identify inactive investors, INACTIVE, investors with a highly skilled job, HIGHLY SKILLED, those with a skilled job, SKILLED, those with low skilled jobs, LOW SKILL, and investors who are professional liberals, INDEPENDENT WORKERS. Investor's residence is also controlled for since investors who live in the metropolitan areas are usually more educated, are more likely to be wealthier and employed in the financial sector and consequently to have access to better quality information. Thus, I distinguish investors who reside in Lisbon, LISBON, from those who reside in Porto, PORTO, which are the two largest Portuguese cities, from investors who reside elsewhere, OTHER. 


\section{Table 1: The Participation Decision (Probit Model)}

\begin{tabular}{|c|c|c|c|c|c|c|}
\hline & & & & & & \\
\hline Male & $\begin{array}{r}0.256 \\
8.80\end{array}$ & $* * *$ & $\begin{array}{r}0.089 \\
2.12\end{array}$ & $* *$ & $\begin{array}{r}0.083 \\
1.95\end{array}$ & $*$ \\
\hline Age & $\begin{array}{r}-0.013 \\
-3.05\end{array}$ & $* * *$ & $\begin{array}{r}-0.020 \\
-4.34\end{array}$ & $* * *$ & $\begin{array}{r}-0.020 \\
-4.35\end{array}$ & $* * *$ \\
\hline Age squared & $\begin{array}{r}0.0000 \\
1.18\end{array}$ & & $\begin{array}{r}0.0001 \\
2.80\end{array}$ & $* * *$ & $\begin{array}{r}0.0001 \\
2.76\end{array}$ & $* * *$ \\
\hline Married & $\begin{array}{r}-0.008 \\
-0.29\end{array}$ & & $\begin{array}{r}0.071 \\
1.93\end{array}$ & $*$ & $\begin{array}{r}0.072 \\
1.97\end{array}$ & $* *$ \\
\hline High education & $\begin{array}{r}-0.125 \\
-2.37\end{array}$ & ** & $\begin{array}{r}-0.066 \\
-1.09\end{array}$ & & $\begin{array}{r}-0.078 \\
-1.28\end{array}$ & \\
\hline Intermediate educ. & $\begin{array}{r}-0.105 \\
-3.43\end{array}$ & $* * *$ & $\begin{array}{r}-0.074 \\
-2.04\end{array}$ & $* *$ & $\begin{array}{r}-0.067 \\
-1.84\end{array}$ & * \\
\hline Highly skilled & $\begin{array}{r}-0.112 \\
-2.87\end{array}$ & $* * *$ & $\begin{array}{r}-0.106 \\
-1.93\end{array}$ & * & $\begin{array}{r}-0.108 \\
-1.96\end{array}$ & $* *$ \\
\hline Skilled & $\begin{array}{r}-0.344 \\
-5.82\end{array}$ & $* * *$ & $\begin{array}{r}-0.341 \\
-5.12\end{array}$ & $* * *$ & $\begin{array}{r}-0.345 \\
-5.18\end{array}$ & *** \\
\hline Low skill & $\begin{array}{r}0.044 \\
1.09\end{array}$ & & $\begin{array}{r}-0.017 \\
-0.37\end{array}$ & & $\begin{array}{r}-0.029 \\
-0.61\end{array}$ & \\
\hline Independent workers & $\begin{array}{r}-0.043 \\
-1.13\end{array}$ & & $\begin{array}{r}-0.078 \\
-1.46\end{array}$ & & $\begin{array}{r}-0.099 \\
-1.79\end{array}$ & * \\
\hline Lisbon & $\begin{array}{r}0.020 \\
0.83\end{array}$ & & $\begin{array}{r}0.050 \\
1.41\end{array}$ & & $\begin{array}{r}0.032 \\
0.87\end{array}$ & \\
\hline Porto & $\begin{array}{r}-0.006 \\
-0.17\end{array}$ & & $\begin{array}{r}0.094 \\
1.57\end{array}$ & & $\begin{array}{r}0.085 \\
1.43\end{array}$ & \\
\hline Overconfidence & & & $\begin{array}{r}0.109 \\
2.58\end{array}$ & ${ }^{* * *}$ & & \\
\hline Better than average & & & & & $\begin{array}{r}-0.049 \\
-1.27\end{array}$ & \\
\hline Disposition & & & $\begin{array}{r}0.528 \\
16.84\end{array}$ & $* * *$ & $\begin{array}{r}0.531 \\
17.01\end{array}$ & $* * *$ \\
\hline Gambling & & & $\begin{array}{r}0.084 \\
1.75\end{array}$ & * & $\begin{array}{r}0.077 \\
1.64\end{array}$ & * \\
\hline Low return & & & $\begin{array}{r}0.050 \\
1.49\end{array}$ & & $\begin{array}{r}0.095 \\
3.46\end{array}$ & $* * *$ \\
\hline № obs with $Y=1$ & 1702 & & 1702 & & 1702 & \\
\hline № observations & 52767 & & 52767 & & 52767 & \\
\hline LR stat. & 313 & & 1677 & & 1672 & \\
\hline Prob. & 0.00 & & 0.00 & & 0.00 & \\
\hline
\end{tabular}

Obs: (i) z-stats in italics; (ii) *,** and *** denote statistical significance at $10 \%, 5 \%$ and $1 \%$ respectively; (iii) the models include a constant as well.

The probit model is estimated by maximum likelihood, and the results are in Table 1. The results of the base model (column [1]) confirm that investors in warrants and investors in stocks do have different socio-demographic characteristics. In fact, 
younger and less educated men are more likely to invest in warrants, and investors with higher skilled jobs are more likely to invest only in stocks. As regards residence, living in the largest cities does not allow any discrimination between investors in stocks and in warrants. Marital status is not a distinguishing factor as well.

In columns [2] and [3] of Table 1 I introduce the behavioral characteristics of investors (overconfidence, better than average, disposition and gambling). Overconfidence can lead investors to trade financial instruments in which they are not accurately familiar with. Overconfident investors have been associated with excessive risk taking (Dorn and Huberman 2005; Nosic and Weber 2010), and this means that they are more prone to take on risk for which there is no apparent reward. Also, overconfident investors tend to think they are above average regarding their investment skills (Taylor and Brown 1988) and consequently may invest more in complex financial instruments. I find that the better than average effect does not have a strong impact on the participation decision, but overconfident investors are more prone to invest in warrants.

The disposition effect, defined as the tendency to sell winning stocks too early while riding losing stocks too long, has also been considered to have an impact on the trading behavior of individual investors, and is a case of reference point dependent behavior since investors behave differently when they are in the gain zone than when they are in the loss zone. The disposition effect has been found in retail as well as in professional investors, and it has been found in stock (Odean 1998b, Grinblatt and Keloharju 2001, Dhar and Zhu 2002, for example) and in mutual fund investors (Bailey et al. 2011). I consider that disposition-prone investors may also adjust their behavior 
as regards the investment in warrants, a complex financial instrument. ${ }^{10}$ Thus, if an investor exhibits disposition effect in his/her stock trading activity then this behavioral bias may also have an impact on the decision to participate in the market for warrants. The DISPOSITION variable is the proxy I use; it is a binary variable, equal to one if the investor exhibits disposition behavior in the stock trading activity, and zero otherwise.

Similarly, recent research postulates that some investors view trading in the stock market as an opportunity to gamble. Barber et al. (2009), for example, document that, in Taiwan, the introduction of the government-sponsored lottery did significantly reduce the stock market turnover, and the authors conclude that part of the excessive trading of individual investors is motivated by their gambling desire. It has also been argued that gambling may justify investors' irrationality when they opt for derivative products. In fact, retail investors may decide not to be informed about product complexity and thus choose randomly with the help of commission-based incentivized distributors, which provides a rationale for product overpricing (Bernard et al. 2010). Campbell (2006), on the other hand, argues that either investors make random decisions or product distributors are very successful in marketing and selling. Nicolaus (2010) finds a pattern of observations that is likely to be driven by speculative purposes. One way to account for the investors' gambling desire is to consider that investors who do not use any source of information at all (i.e., they are not informed about financial markets and instruments) are gamblers and make random decisions. The GAMBLING variable is the proxy used; it is a binary variable, equal to one if the investor does not use any source to get information about financial markets and instruments.

\footnotetext{
10 Ofir and Wiener (2012) conclude that structured retail products are designed to capture investor biased behavior such as the disposition effect.
} 
The hypothesis that the investor's performance in the stock market influences the investment in warrants is also tested. Mendes (2012) argues that investors with low success in the investment in stocks are more likely to invest in more leveraged products (that is, warrants) in an attempt to recover losses suffered. Thus, a binary variable is defined for the lower quartile of performance of equity investments. However, information on the composition of the portfolio of each investor is not available, and the methodology of Seru et al. (2010) (also used in Mendes 2012, and Abreu et al. 2011) is followed. Therefore, the performance of investors is measured by the 30-day unweighted average return of the stocks purchased by the investor. Accordingly, the variable LOW RETURN is a dummy variable equal to 1 if the investor's return on the investment in stocks is in the lowest quartile of returns. ${ }^{11}$

I conclude that overconfident investors are indeed more likely to invest in warrants, but the better than average effect does not have a significant impact. This is consistent with Coval and Shumway (2005) findings on future traders. Overly wedded to prior beliefs, an overconfident investor may discount negative public information that pushes down prices, thus holding on and taking on excessive risk.

As regards the impact of disposition, its effect is quite strong and I conclude that investors who exhibit disposition effect in their stock trading activity are more likely to invest and trade in warrants. This result is in line with the findings of Ofir and Wiener (2012); using an experiment, the authors find evidence of the prevalence of the disposition effect on investors' decision-making regarding structured retail products.

\footnotetext{
${ }^{11}$ Related to this literature, Merkle and Weber (2014) claim that expectations are relevant to explain changes in the risky portfolio of individual investors. Nevertheless, I do not have information on investors' expectations and cannot include this into the analysis.
} 
Regarding the possibility that some individuals may participate in the stock (and derivatives) market because of their risk-loving attitude, albeit not very strong from a statistical standpoint, the gambling attitude seems to lead more investors to participate in the warrants market, and this is evidence of a behavioral bias in the market for this complex financial instrument.

One should also notice the high statistical significance on the LOW RETURN variable in the model with the better than average effect, and its lack of statistical significance (although with a positive coefficient) in the model with the OVERCONFIDENCE variable. This could be the result of its correlation with the latter variable. ${ }^{12}$ Nevertheless, one can conclude that there is evidence that investors with low success from the investment in stocks are more likely to invest in warrants. This suggests that the investment in warrants (and similarly the investment in other derivative instruments) may be an attempt to compensate for the losses investors incur when investing in stocks.

12 The OVERCONFIDENCE variable combines lower returns with higher trading activity. 


\section{Trading activity}

The decision to participate in the warrants market is one of the decisions an investor makes. Conditioned to this decision, in a second step the investor decides on whether to trade more or to trade less. In Portugal, both the stock market and the warrants market can be considered liquid markets. One may recall that warrants are a financial instrument with a large success in Portugal, and investors traded warrants very actively (Mendes 2012). Thus, liquidity does not seem to be a clear distinguishing factor of the stock and the warrants markets.

In this section I study whether investors trade stocks differently than warrants. For this purpose, the number of trades each investor makes in either stocks or warrants is used. I am interested in the impact of behavioral biases on the trading activity of individual investors in both types of financial instruments.

Thus, the model's dependent variable is the number of trades in warrants (or stocks) an investor makes during the sample period. This is a count model, in which the independent variables are those from the previous section. I use a negative binomial count model, estimated by maximum likelihood. Results are in Table 2, and both proxies for overconfidence are tested.

A quick look at the results reported in Table 2 (models [6] and [7]) allows one to conclude that warrants trading is influenced by investors' socio-demographic characteristics and behavioral traits. In fact, education, occupation and age do not have a linear impact on the number of trades: investors with an intermediate academic degree trade more warrants, investors with highly qualified occupations have a trading activity similar to that of inactive investors, and in both cases they trade more than skilled, low skilled and independent workers. Also, investors living in Lisbon trade 
warrants more often. Nevertheless, gender and marital status are not relevant to explain the number of trades in warrants these investors make.

Regarding the behavioral determinants of trading, results show that overconfidence has a positive impact on trading, this variable being significant at the $10 \%$ level, but the better than average proxy is not. Therefore, there is slight evidence that overconfident investors do trade more often. The disposition proxy is significant (at the 5\% level), as it is for the stock trading case (models [4] and [5]). Nevertheless, this coefficient is smaller in models [6] and [7], which means that the impact of the disposition effect is lower when investors trade warrants than when they trade stocks. However, the most interesting finding is related to the sign of the gambling coefficient: it is positive (negative) for the warrants (stocks) case, meaning that the gambling motivated trading is more pronounced in the trading of these derivative instruments. Moreover, the coefficient of the gambling variable is higher than the coefficients of the other behavioral variables. This clearly distinguishes the warrants from the stock market activity, meaning that the search for pleasure in trading increases warrants transactions but instead it decreases the stock trading activity. In other words, when investors are driven for pleasure to trade in financial markets they tend to trade complex products more and to trade simpler and easier to understand financial instruments less.

Finally, although the participation in the warrants market is driven by the existence of lower returns obtained in the investment in stocks, the number of trades in warrants does not depend on the lower success of that investment. 


\section{Table 2: Trading activity - Count model}

\begin{tabular}{|c|c|c|c|c|c|c|c|c|}
\hline Male & $\begin{array}{r}0.351 \\
30.00\end{array}$ & $* * *$ & $\begin{array}{r}0.346 \\
29.98\end{array}$ & $* * *$ & $\begin{array}{r}-0.101 \\
-0.63\end{array}$ & & $\begin{array}{r}-0.063 \\
-0.39\end{array}$ & \\
\hline Age & $\begin{array}{r}0.027 \\
14.27\end{array}$ & $* * *$ & $\begin{array}{r}0.026 \\
14.00\end{array}$ & $* * *$ & $\begin{array}{r}0.143 \\
7.67\end{array}$ & $* * *$ & $\begin{array}{r}0.145 \\
7.75\end{array}$ & $* * *$ \\
\hline Age squared & $\begin{array}{r}-0.0002 \\
-11.35\end{array}$ & $* * *$ & $\begin{array}{r}-0.0002 \\
-11.19\end{array}$ & $* * *$ & $\begin{array}{r}-0.0015 \\
-7.86\end{array}$ & $* * *$ & $\begin{array}{r}-0.0014 \\
-7.82\end{array}$ & $* * *$ \\
\hline Married & $\begin{array}{r}0.022 \\
2.07\end{array}$ & $* *$ & $\begin{array}{r}0.023 \\
2.15\end{array}$ & $* *$ & $\begin{array}{r}0.072 \\
0.53\end{array}$ & & $\begin{array}{r}0.023 \\
0.17\end{array}$ & \\
\hline High education & $\begin{array}{r}-0.176 \\
-8.64\end{array}$ & $* * *$ & $\begin{array}{r}-0.181 \\
-9.08\end{array}$ & $* * *$ & $\begin{array}{r}-0.121 \\
-0.52\end{array}$ & & $\begin{array}{r}-0.040 \\
-0.17\end{array}$ & \\
\hline Intermediate educ. & $\begin{array}{r}-0.134 \\
-10.22\end{array}$ & $* * *$ & $\begin{array}{r}-0.128 \\
-9.97\end{array}$ & $* * *$ & $\begin{array}{r}0.255 \\
2.04\end{array}$ & $* *$ & $\begin{array}{r}0.227 \\
1.82\end{array}$ & * \\
\hline Highly skilled & $\begin{array}{r}0.025 \\
1.65\end{array}$ & $*$ & $\begin{array}{r}0.030 \\
1.95\end{array}$ & $*$ & $\begin{array}{r}-0.182 \\
-0.94\end{array}$ & & $\begin{array}{r}-0.101 \\
-0.53\end{array}$ & \\
\hline Skilled & $\begin{array}{r}-0.263 \\
-12.50\end{array}$ & $* * *$ & $\begin{array}{r}-0.258 \\
-12.26\end{array}$ & $* * *$ & $\begin{array}{r}-0.976 \\
-3.97\end{array}$ & $* * *$ & $\begin{array}{r}-0.910 \\
-3.69\end{array}$ & $* * *$ \\
\hline Low skill & $\begin{array}{r}-0.110 \\
-6.25\end{array}$ & $* * *$ & $\begin{array}{r}-0.112 \\
-6.45\end{array}$ & $* * *$ & $\begin{array}{r}-0.787 \\
-4.71\end{array}$ & $* * *$ & $\begin{array}{r}-0.717 \\
-4.31\end{array}$ & $* * *$ \\
\hline Independent workers & $\begin{array}{r}0.015 \\
0.88\end{array}$ & & $\begin{array}{r}0.001 \\
0.09\end{array}$ & & $\begin{array}{r}-0.761 \\
-3.88\end{array}$ & $* * *$ & $\begin{array}{r}-0.592 \\
-3.14\end{array}$ & $* * *$ \\
\hline Lisbon & $\begin{array}{r}0.033 \\
2.70\end{array}$ & $* * *$ & $\begin{array}{r}0.013 \\
1.19\end{array}$ & & $\begin{array}{r}0.324 \\
2.34\end{array}$ & $* *$ & $\begin{array}{r}0.429 \\
3.39\end{array}$ & $* * *$ \\
\hline Porto & $\begin{array}{r}0.082 \\
5.51\end{array}$ & $* * *$ & $\begin{array}{r}0.054 \\
3.91\end{array}$ & $* * *$ & $\begin{array}{r}0.109 \\
0.47\end{array}$ & & $\begin{array}{r}0.140 \\
0.61\end{array}$ & \\
\hline Overconfidence & & & $\begin{array}{r}0.231 \\
12.72\end{array}$ & $* * *$ & & & $\begin{array}{r}0.246 \\
1.78\end{array}$ & * \\
\hline Better than average & $\begin{array}{r}0.044 \\
3.01\end{array}$ & $* * *$ & & & $\begin{array}{r}-0.304 \\
-1.21\end{array}$ & & & \\
\hline Disposition & $\begin{array}{r}0.931 \\
78.73\end{array}$ & $* * *$ & $\begin{array}{r}0.935 \\
79.10\end{array}$ & $* * *$ & $\begin{array}{r}0.318 \\
2.40\end{array}$ & $* *$ & $\begin{array}{r}0.331 \\
2.50\end{array}$ & $* *$ \\
\hline Gambling & $\begin{array}{r}-0.068 \\
-3.42\end{array}$ & $* * *$ & $\begin{array}{r}-0.081 \\
-4.05\end{array}$ & $* * *$ & $\begin{array}{r}0.340 \\
2.05\end{array}$ & $* *$ & $\begin{array}{r}0.391 \\
2.38\end{array}$ & $* *$ \\
\hline Low return & $\begin{array}{r}-0.191 \\
-17.34\end{array}$ & $* * *$ & $\begin{array}{r}-0.261 \\
-21.34\end{array}$ & $* * *$ & $\begin{array}{r}0.024 \\
0.24\end{array}$ & & $\begin{array}{r}-0.090 \\
-0.81\end{array}$ & \\
\hline № observations & 52767 & & 52767 & & 1702 & & 1702 & \\
\hline LR stat. & 1666999 & & 1667157 & & 332031 & & 332029 & \\
\hline Prob. & 0.00 & & 0.00 & & 0.00 & & 0.00 & \\
\hline
\end{tabular}

Obs: (i) z-stats in italics; (ii) * ,** and *** denote statistical significance at $10 \%, 5 \%$ and $1 \%$ respectively;

(iii) the models include a constant as well. 
In what regards the stock market, models [4] and [5] allow one to conclude that there are differences in the socio-demographic determinants of the stock and of the warrants trading activity. Less educated, highly skilled men trade stocks more frequently, and the effect of age is non-linear. Marital status does seem to play a role, and as for the place of residence, investors from Lisbon and Porto seem to trade more in stocks than other investors. This set of results differs from those reported by Abreu and Mendes (2012). In fact, using a survey of the Portuguese population (not actual transactions data), Abreu and Mendes (2012) conclude that gender, education and occupation were not distinctive factors of the trading activity of Portuguese investors.

As for overconfidence and the better than average effect, both proxies are highly significant and with a positive sign, meaning that overconfident investors trade stocks more often and that those who feel they are better than average also trade stocks more often. This result is in line with the findings of Odean (1998b), Barber and Odean (2001), Glaser and Weber (2007), Deaves et al. (2009), and Graham et al. (2009), among others.

Disposition-prone investors also trade stocks more often. One characteristic of investors who have this behavioral bias is that they hold on too long to the stocks in the portfolio in down markets, and sell them too soon in up markets, thus not taking full advantage of the existing opportunities in the market. The sample period includes two bull market sub-periods (1997/2000 and 2002/2006) and one bear market subperiod (2000/2002), and thus disposition-motivated trading could be more intense by these investors not only because there is only one down sub-period but also because the bull market sub-periods are lengthier than the bear sub-period.

Gambling and low returns lead to lower stock trading activity: the coefficients of both variables are statistically significant and negative, meaning that gamblers trade stocks 
less often and that lower returns on the investment in stocks also leads investors to be less active in the stock market.

\section{Trading frequency}

The number of trades was the dependent variable in the previous section, but this dependent variable does not account for the period of time in which the investor is active in the market. To control for the time span in which investors are active in the market I now consider that the investors' trading activity starts when the investor makes the first trade, and assume she is active all the way to the last day of the sample. Therefore, it is possible to look at the trading frequency computing the average number of warrant trades per year, which is the new dependent variable (in logs). The independent variables are all the same as in the previous section, and this new model is estimated by OLS.

Additionally, I search for heterogeneity among investors. Investors with a high frequency of trading may have a different profile and motives to trade than investors that only trade sporadically. Thereafter, a quantile regression approach is used to document if the number of trades in warrants per year responds differently to variations in the variables which are expected to affect trading.

Contrary to least squares regression where all of the inferences pertain only to the mean trading frequency, quantile regression techniques allow one to study the impact of each covariate along the whole distribution and not just the mean, and thus the estimation of the impact of investors' heterogeneity upon trading frequency. 
Table 3 Trading frequency in warrants - Quantile regression

\begin{tabular}{|c|c|c|c|c|c|c|c|c|c|c|}
\hline & OLS & & $\begin{array}{c}\text { Quant. } \\
10\end{array}$ & & $\begin{array}{c}\text { Quant. } \\
25\end{array}$ & & $\begin{array}{c}\text { Quant. } \\
50\end{array}$ & & $\begin{array}{c}\text { Quant. } \\
75\end{array}$ & $\begin{array}{c}\text { Quant. } \\
90\end{array}$ \\
\hline & [8] & & [9] & & {$[10]$} & & [11] & & [12] & [13] \\
\hline Male & $\begin{array}{r}0.004 \\
0.03\end{array}$ & & $\begin{array}{r}-0.001 \\
-0.02\end{array}$ & & $\begin{array}{r}-0.032 \\
-0.26\end{array}$ & & $\begin{array}{r}0.012 \\
0.07\end{array}$ & & $\begin{array}{r}0.120 \\
0.45\end{array}$ & $\begin{array}{r}0.112 \\
0.39\end{array}$ \\
\hline Age & $\begin{array}{r}-0.008 \\
-0.38\end{array}$ & & $\begin{array}{r}-0.038 \\
-3.43\end{array}$ & *** & $\begin{array}{r}-0.060 \\
-2.95\end{array}$ & *** & $\begin{array}{r}-0.009 \\
-0.03\end{array}$ & & $\begin{array}{r}0.011 \\
0.29\end{array}$ & $\begin{array}{r}0.043 \\
0.94\end{array}$ \\
\hline Age squared & $\begin{array}{r}-0.0002 \\
-1.11\end{array}$ & & $\begin{array}{r}0.0003 \\
2.61\end{array}$ & $* * *$ & $\begin{array}{r}0.0003 \\
1.67\end{array}$ & $*$ & $\begin{array}{r}-0.0003 \\
-0.94\end{array}$ & & $\begin{array}{r}-0.0005 \\
-1.35\end{array}$ & $\begin{array}{r}-0.0007 \\
-1.52\end{array}$ \\
\hline Married & $\begin{array}{r}0.085 \\
0.75\end{array}$ & & $\begin{array}{r}-0.026 \\
-0.35\end{array}$ & & $\begin{array}{r}0.001 \\
0.01\end{array}$ & & $\begin{array}{r}0.301 \\
1.95\end{array}$ & $* *$ & $\begin{array}{r}0.059 \\
0.27\end{array}$ & $\begin{array}{r}0.043 \\
0.17\end{array}$ \\
\hline High education & $\begin{array}{r}0.245 \\
0.97\end{array}$ & & $\begin{array}{r}0.127 \\
0.77\end{array}$ & & $\begin{array}{r}0.343 \\
1.45\end{array}$ & & $\begin{array}{r}0.366 \\
1.23\end{array}$ & & $\begin{array}{r}0.333 \\
0.61\end{array}$ & $\begin{array}{r}0.049 \\
0.09\end{array}$ \\
\hline Intermediate educ. & $\begin{array}{r}0.156 \\
1.17\end{array}$ & & $\begin{array}{r}0.131 \\
1.31\end{array}$ & & $\begin{array}{r}0.315 \\
2.22\end{array}$ & ** & $\begin{array}{r}0.145 \\
0.76\end{array}$ & & $\begin{array}{r}-0.047 \\
-0.21\end{array}$ & $\begin{array}{r}0.004 \\
0.01\end{array}$ \\
\hline Highly skilled & $\begin{array}{r}-0.332 \\
-2.02\end{array}$ & $* *$ & $\begin{array}{r}-0.097 \\
-0.84\end{array}$ & & $\begin{array}{r}-0.309 \\
-1.92\end{array}$ & * & $\begin{array}{r}-0.602 \\
-2.66\end{array}$ & $* * *$ & $\begin{array}{r}-0.366 \\
-1.15\end{array}$ & $\begin{array}{r}-0.017 \\
-0.05\end{array}$ \\
\hline Skilled & $\begin{array}{r}-0.505 \\
-1.84\end{array}$ & * & $\begin{array}{r}-0.078 \\
-0.47\end{array}$ & & $\begin{array}{r}-0.457 \\
-1.93\end{array}$ & $*$ & $\begin{array}{r}-0.615 \\
-1.72\end{array}$ & $*$ & $\begin{array}{r}-0.267 \\
-0.62\end{array}$ & $\begin{array}{r}-0.377 \\
-0.74\end{array}$ \\
\hline Low skill & $\begin{array}{r}-0.366 \\
-2.14\end{array}$ & $* *$ & $\begin{array}{r}0.051 \\
0.38\end{array}$ & & $\begin{array}{r}-0.191 \\
-1.07\end{array}$ & & $\begin{array}{r}-0.407 \\
-1.98\end{array}$ & $* *$ & $\begin{array}{c}-0.564 \\
-1.70\end{array} *$ & $\begin{array}{r}-0.528 \\
-1.48\end{array}$ \\
\hline Independent workers & $\begin{array}{r}-0.264 \\
-1.55\end{array}$ & & $\begin{array}{r}-0.051 \\
-0.41\end{array}$ & & $\begin{array}{r}-0.253 \\
-1.48\end{array}$ & & $\begin{array}{r}-0.335 \\
-1.61\end{array}$ & & $\begin{array}{r}-0.337 \\
-0.97\end{array}$ & $\begin{array}{r}-0.324 \\
-0.95\end{array}$ \\
\hline Lisbon & $\begin{array}{r}0.242 \\
1.81\end{array}$ & * & $\begin{array}{r}0.076 \\
0.90\end{array}$ & & $\begin{array}{r}0.284 \\
2.42\end{array}$ & $* *$ & $\begin{array}{r}0.432 \\
2.56\end{array}$ & $* *$ & $\begin{array}{r}0.273 \\
0.96\end{array}$ & $\begin{array}{r}0.177 \\
0.70\end{array}$ \\
\hline Porto & $\begin{array}{r}0.091 \\
0.57\end{array}$ & & $\begin{array}{r}-0.024 \\
-0.23\end{array}$ & & $\begin{array}{r}0.002 \\
0.01\end{array}$ & & $\begin{array}{r}0.232 \\
1.07\end{array}$ & & $\begin{array}{r}0.256 \\
0.91\end{array}$ & $\begin{array}{r}-0.261 \\
-0.95\end{array}$ \\
\hline Better than average & $\begin{array}{r}-0.062 \\
-0.39\end{array}$ & & $\begin{array}{r}-0.047 \\
-0.45\end{array}$ & & $\begin{array}{r}-0.078 \\
-0.52\end{array}$ & & $\begin{array}{r}0.043 \\
0.22\end{array}$ & & $\begin{array}{r}-0.064 \\
-0.22\end{array}$ & $\begin{array}{r}-0.293 \\
-0.78\end{array}$ \\
\hline Disposition & $\begin{array}{r}0.533 \\
3.70\end{array}$ & $* * *$ & $\begin{array}{r}0.003 \\
0.04\end{array}$ & & $\begin{array}{r}0.251 \\
2.20\end{array}$ & ** & $\begin{array}{r}0.893 \\
5.17\end{array}$ & $* * *$ & $\begin{array}{c}0.9155^{* * *} \\
3.19\end{array}$ & $\begin{array}{r}0.386 \\
1.35\end{array}$ \\
\hline Gambling & $\begin{array}{r}0.305 \\
1.65\end{array}$ & * & $\begin{array}{r}0.279 \\
1.73\end{array}$ & * & $\begin{array}{r}0.549 \\
2.29\end{array}$ & $* *$ & $\begin{array}{r}0.687 \\
2.75\end{array}$ & $* * *$ & $\begin{array}{r}0.283 \\
0.87\end{array}$ & $\begin{array}{r}0.035 \\
0.10\end{array}$ \\
\hline Low return & $\begin{array}{r}0.105 \\
0.93\end{array}$ & & $\begin{array}{r}0.169 \\
2.15\end{array}$ & $* *$ & $\begin{array}{r}0.278 \\
2.61\end{array}$ & $* * *$ & $\begin{array}{r}0.201 \\
1.41\end{array}$ & & $\begin{array}{r}-0.014 \\
-0.07\end{array}$ & $\begin{array}{r}-0.203 \\
-0.86\end{array}$ \\
\hline Adj R2 / Quasi-LR stat. & $7.56 \%$ & & 52.40 & & 146.70 & & 138.10 & & 72.00 & 33.10 \\
\hline F-stat / Prob. & 8.7 & & 0.00 & & 0.00 & & 0.00 & & 0.00 & 0.11 \\
\hline
\end{tabular}

Obs: (i) t-stats in italics; (ii) *, ** and *** denote statistical significance at $10 \%, 5 \%$ and $1 \%$ respectively;

(iii) the models include a constant as well.

Results of the OLS estimation and of the quantile regression model are shown in Table 3, where one can confirm the superiority of the quantile regression approach 
for it allows the discrimination of investors. ${ }^{13}$ If one is left with the OLS estimates we would be (wrongly) assigning all investors the same impact of the independent variables, which is not the case. Additionally, the best estimation results (measured by the number of coefficients with statistical significance) are those for the quantiles 25 and 50 of the (log of) annual number of trades in warrants. Investors who trade warrants less frequently (quantile 10) as well as those who trade this derivative more frequently (quantile 90) are quite heterogeneous, and no clear socio-demographic characteristics emerge. Among those with more intensive trading one cannot find any distinguishing characteristic: in fact, none of the explanatory variables is significant in quantile 90 , not even at the $10 \%$ significance level. Another very interesting result is that, for most of the statistically significant variables, their impact on the (log of) the average number of trades in warrants increases with the average number of trades of the investor.

Disposition and gambler's biases are significant determinants of trading for intermediate quantiles. Results show that, when statistically significant, the coefficients of the disposition and the gambler variables increase with trading frequency, which means that the impact of these behavioral biases is stronger for investors who trade warrants more frequently. For the disposition coefficient, investors with the $75 \%$ higher average number of trades per year do have a highly significant 0.915 coefficient whilst those with the $25 \%$ lowest average number of trades exhibit a 0.251 coefficient. Thus, up to a certain level of trading intensity, the impact of the disposition and gambling biases increases with the intensity of trading.

\footnotetext{
${ }^{13}$ The results of the estimation of the models with the OVERCONFIDENCE variable are not presented in order to save space, but they are essentially similar to the ones presented in this Table 3.
} 


\section{Concluding remarks}

This paper examines the socio-demographic characteristics of retail investors in warrants, and discusses the hypothesis that some behavioral biases do have an impact on the investors' predisposition to invest and trade in warrants, a complex financial instrument. Amongst the most relevant conclusions of this empirical application, one finds that the socio-demographic and behavioral characteristics of investors in warrants are different from those of investors in stocks. Firstly, investors in warrants have a particular socio-demographic profile: younger and less educated men are more likely to invest in warrants. Secondly, investors' behavioral biases are particularly relevant to understand investor's participation in the market of this complex financial instrument. In fact, overconfident and disposition-prone investors as well as investors exhibiting a gambling attitude are more likely to invest and trade in warrants. Moreover, disposition-prone investors are more likely to trade warrants more frequently.

Secondly, there is a distinguishing characteristic of investors who trade warrants: the gambling motive increases warrants transactions but decreases the stock trading activity among these investors. In other words, when investors are driven to trade in financial markets for pleasure they tend to trade complex products more and to trade simple and easier to understand financial instruments less.

Finally, the quantile analyses show that the disposition and the gambler's effect are the more relevant to explain the frequency of trading the higher the intensity of trading, except for high trading frequency investors who seem to be heterogeneous and without a clear cut social-demographic and behavioral profile. 
References

Abreu, M. and V. Mendes (2010), "Financial Literacy and Portfolio Diversification", Quantitative Finance 10(5), 515-528.

Abreu, M. and V. Mendes (2012), "Information, Overconfidence and Trading: Do the Sources of Information Matter?", Journal of Economic Psychology 33, 868-881.

Abreu, M., V. Mendes, J. Santos (2011), "Home Country Bias: Does Domestic Experience Help Investors Enter Foreign Markets?", Journal of Banking and Finance 35(9), 2330-2340.

Bailey, W., A. Kumar and D. Ng (2008), "Foreign Investments of US Individual Investors: Causes and Consequences," Management Science 54(3), 443-459.

Bailey, W., A. Kumar and D. Ng (2011), "Behavioral Biases of Mutual Fund Investors", Journal of Financial Economics 102(1), 1-27.

Barber, B. and T. Odean (2000), "Trading Is Hazardous to Your Wealth: The Common Stock Investment Performance of Individual Investors", Journal of Finance 55(2), 773-806.

Barber, B. and T. Odean (2001), "Boys Will Be Boys: Gender, Overconfidence, and Common Stock Investment", Quarterly Journal of Economics 116(1), 261-292.

Barber, B., Y. Lee, Y. Liu, and T. Odean (2009), “Just How Much Do Individual Investors Lose by Trading?", Review of Financial Studies 22, 609-632.

Barberis, N. and W. Xiong (2009), "What Drives the Disposition Effect? An Analysis of a Long-Standing Preference-Based Explanation", Journal of Finance 64(2), 751784.

Bernard, C., P. Boyle and W. Gornall (2010), "Locally-Capped Investment Products and the Retail Investor", Working Paper, available at SSRN. 
Calvet, L., J. Campbell and P. Sodini (2009), "Fight or Flight? Portfolio Rebalancing by Individual Investor", Quarterly Journal of Economics 124(1), 301-348.

Campbell, J. (2006), "Household Finance”, Journal of Finance 61, 1553-1604.

Christelis, D., T. Japelli and M. Padula (2010), "Cognitive Abilities and Portfolio Choice", European Economic Review 54, 18-38.

Christiansen, C., J. Joensenand and J. Rangvid (2008), "Are Economists More Likely to Hold Stocks?", Review of Finance 12(3), 465-496.

Coval, J. and T. Shumway (2005), “Do Behavioral Biases Affect Prices?”, Journal of Finance 60, 1-34.

DaSilva, A. and C. Giannikos (2006), "Higher Risk Aversion in Older Agents: Its Asset Pricing Implications", Columbia University, Department of Economics Working Paper, Available at SSRN: https://ssrn.com/abstract $=955958$ or http://dx.doi.org/10.2139/ssrn.955958.

Deaves, R., E. Lüders and G. Luo (2009), “An Experimental Test of the Impact of Overconfidence and Gender on Trading Activity", Review of Finance 13(3), 555-575.

DeBondt, W. and R. Thaler (1995), "Financial Decision-making in Markets and Firms: A Behavioral Perspective”, in R. Jarrow, V. Maksimovic and W. Ziemba (eds.), Handbooks in Operations Research and Management Science: Finance, Amsterdam: Elsevier.

Dhar, R. and N. Zhu (2002), “Up Close and Personal: An Individual Level Analysis of the Disposition Effect", Yale ICF Working Paper 02-20.

Dorn, D. and G. Huberman (2005), "Talk and Action: What Individual Investors Say and What They Do", Review of Finance 9(4), 437-481.

Dorn, D. and P. Sengmueller, (2009), “Trading as Entertainment?", Management Science 55(4), 591-603. 
Glaser, M. and M. Weber (2007), "Overconfidence and Trading Volume", Geneva Risk Insurance Review 32, 1-36.

Goetzmann, W. and A. Kumar (2008), "Equity Portfolio Diversification", Review of Finance 12(3), 433-463.

Goetzmann, W. and M. Massa (2003), "Disposition Matters: Volume, Volatility and Price Impact of a Behavioral Bias", NBER Working Paper 9499.

Graham, J., C. Harvey and H. Huang (2009), "Investor Competence, Trading Frequency, and Home Bias", Management Science 55(7), 1094-1106.

Grinblatt, M. and M. Keloharju (2001), "What Makes Investors Trade?”, Journal of Finance 56(2), 589-616.

Grinblatt, M. and M. Keloharju (2009), "Sensation Seeking, Overconfidence, and Trading Activity", Journal of Finance 64(2), 549-578.

Lakonishok, J. and S. Smidt (1986), "Volume For Winners and Losers: Taxation and Other Motives For Stock Trading", Journal of Finance 41(4), 951-974.

Lusardi, A. and O. Mitchell (2009), "How Ordinary Consumers Make Complex Economic Decisions: Financial Literacy and Retirement Readiness", NBER Working Paper 15350.

Mendes, V. (2012), "The Investor in Warrants", CEFAGE-UE Working Paper 2012/19.

Muermann, A. and J. Volkman (2006), "Regret, Pride, and the Disposition Effect", Population Aging Research Center, PARC Working Paper Series WPS 06-07.

Nicolaus, D. (2010), "Derivative Choices of Retail Investors: Evidence from Germany", Working Paper. Available at SSRN: https://ssrn.com/abstract=1716777.

Nosic, A. and M. Weber (2010), "How Riskily Do I Invest? The Role of Risk Attitudes, Risk Perceptions, and Overconfidence", Decision Analysis 7(3), 282-301. 
Odean, T. (1998a), “Are Investors Reluctant to Realize Their Losses?”, Journal of Finance 53(5), 1775-1798.

Odean, T. (1998b), "Volume, Volatility, Price, and Profit When All Traders Are Above Average", Journal of Finance 53(6), 1887-1934.

Odean, T. (1999), “Do Investors Trade Too Much?”, American Economic Review 89, 1279-1298.

Ofir, M. and Z. Wiener (2012), "Investment in Financial Structured Products From a Rational and Behavioral Choice Perspectives", Working paper, available at SSRN: http://ssrn.com/abstract=2193282.

Proyer, René (2017), A new structural model for the study of adult playfulness: Assessment and exploration of an understudied individual differences variable, Personality and Individual Differences 108, 113-122.

Schmitz, P., M. Glaser and M. Weber (2009), “Individual Investor Sentiment and Stock Returns - What Do We Learn from Warrant Traders?”, Working Paper, available at SSRN http://ssrn.com/abstract=923526 .

Seru, A., T. Shumway and N. Stoffman (2010), "Learning By Trading", Review of Financial Studies 23(2), 705-739.

Shapira, Z. and I. Venezia (2001), "Patterns of Behavior of Professionally Managed and Independent Investors", Journal of Banking and Finance 25(8), 1573-1587.

Shefrin, H. and M. Statman (1984), "The Disposition to Sell Winners Too Early and Ride Losers Too Long: Theory and Evidence", Journal of Finance 40(3), 777-790.

Statman, M., S. Thorley and K. Vorkink (2006), "Investor Overconfidence and Trading Volume", Review of Financial Studies 19, 1531-1565.

Summers, B. and D. Duxbury (2012), "Decision-dependent Emotions and Behavioral Anomalies", Organizational Behavior and Human Decision Processes. 
Taylor, S. and J. Brown (1988), "Illusion and Well Being: A Social Psychology Perspective on Mental Health", Psychological Bulletin 103, 193-210.

Zuckerman, M. (1994), Behavioral Expressions and Biosocial Bases of Sensation Seeking. Cambridge University Press, Cambridge, UK. 